\title{
Adatok az Aggteleki-karszt barlangjainak Mesostigmata atka faunájához (Acari)
}

\author{
KONTSCHÁN JENŐ \\ Magyar Tudományos Akadémia, Agrártudományi Kutatóközpont, \\ Növényvédelmi Intézet, Állattani Osztály, 1525 Budapest, Pf. 102. \\ E-mail: kontschan.jeno@agrar.mta.hu
}

Összefoglalás. Az Aggteleki-karszt két barlangjának vizsgálata során 14 Mesostigmata atkafaj került elö. Három faj (Cyrtolaelaps chiropterae KARG, 1971; Cyrtolaelaps mucronatus (G. \& R. CANESTRINI, 1881); Nenteria dobrogensis FEIDER \& HuȚU, 1971) Magyarország faunájára új. A Baradla-barlangból 13 faj, a Vass Imre-barlangból hat faj került elő, három faj mindkét barlangban előfordult.

Kulcsszavak: Mesostigmata atkák, barlang, Aggteleki-karszt.

\section{Bevezetés}

Az Aggteleki-karszt barlangjai zoológiai kutatásának nagy hagyománya van hazánkban. Bár már a 19. század végéről ismerünk adatokat a barlangok parazita atkáiról (PETÉNYI 1854), az első szabadon élő atkákat bemutató eredményekről SZALAY LÁSZLÓ számolt be az Állattani Szakosztály 1931. november 6-i ülésén, ahol a DUDICH ENDRE professzor által 1928 októbere és 1929 decembere között a Baradlában gyüjtött pókszabásúak bemutatása során a megtalált Gamasida (=Mesostigmata) fajokról is említést tett (SzALAY 1931). DUDICH professzor intenzív feltáró munkájának köszönhetően az általa készített „Baradla monográfiában" (DUDICH 1932) már 13 szabadon élő, nem parazita életmódú Gamasida fajról számolt be. A megtalált fajok java részét hemitroglobiontként, míg két fajt pseudotroglobiontként említ. A Baradla-barlang szlovákiai részén, a Domica-barlangban 1997-ben gyüjtöttek különböző gerinctelen csoportokat. Ennek eredményeinek bemutatása során (KovÁČ et al. 2005) a Mesostigmata rendböl 21 fajt közöltek a Gamasina alrendböl, míg 5 fajt az Uropodina alrendből. Később ÁCS \& KONTSCHÁN (2014) említ néhány, a Macrochelidae családba tartozó atka fajt a Baradla-barlangból, melyek szintén a jelen munka alapját adó, 2013-2014-es vizsgálatok során kerültek begyüjtésre.

A vizsgálatok során arra is kerestem a választ, hogy mennyire tér el a barlangi fauna a barlang bejárata közelében, kint megtalálható faunától. Ennek érdekében néhány mintát vettünk ebből a régióból is. 


\section{Anyag és módszer}

A vizsgálathoz az atkákat három módszer segítségével gyüjtöttük 2013-2014-ben számos alkalommal. Egyeléses módszerrel gyüjtöttük a szabad szemmel megfigyelhető egyedeket, amelyek egy ecset segítségével kerültek az alkoholos fiolába. Talajcsapdázást is alkalmaztunk, amely során kisméretü talajcsapdákat ástunk le a talajba. Ezek mellett Berlesemódszerrel a már a barlangban benn levő szerves anyagot (pl. denevérguanót, korhadó faanyagot), valamint általunk a barlangba kihelyezett, sterilizált avart, illetve faforgácsot futtatunk ki papírtölcséres futtató segítségével. Szintén Berlese-módszert alkalmaztunk a barlangok közelében gyüjtött felszíni minták esetében.

Az atkákat Peter luptacik, Angyal Dorottya, BalÁzs Gergely, DÁNyi LÁszló és KONTSCHÁN JENÖ gyüjtötte.

Azért, hogy teljesebb képet kapjunk a barlangok Mesostigmata atkáiról, a barlangi és a barlangon kívüli élőhelyek, valamint a különböző barlangokból ismert atkák összehasonlító táblázatánál szerepeltetem a már korábban ismertetett (ÁCS \& KONTSCHÁN 2014), de jelen munka alapját adó vizsgálatból származó fajokat is.

Az alkoholba helyezett atkákat tejsavas kezeléssel világosítottam át, majd rögzített preparátumot készítettem tárgylemezen. Leica DM1000 típusú fénymikroszkóp segítségével azonosítottam a fajokat, és illusztrációt készítettem róluk a mikroszkópra szerelt rajzolófeltét segítségével.

\section{Eredmények}

A vizsgálatok során az Aggteleki-karszt két barlangjából 14 Mesostigmata atkafaj került elő (1. táblázat), ebből 10 faj a Gamasina alrendből, míg négy faj az Uropodina alrendből származik. A megtalált 14 fajból három faj Magyarország területéről eddig nem lett kimutatva, míg az Aggteleki-karszt barlangjaira 8 faj bizonyult újnak. A Baradla-barlangból 13 fajt, a Vass Imre-barlangból 6 fajt mutattam ki. A Baradla- és a Vass Imre-barlang közös fajainak száma három. Troglobiont fajt nem találtunk a Mesostigmata atkák között, de hat fajt az eutroglofil fajok közé sorolhatunk. 
1. táblázat. A jelen kutatásban, a Domica-barlang kutatása során (KovÁČ et al. 2005) és a Baradla monográfiában (DUDICH 1932) megtalált fajok listája (+ = Baradla-Domica-barlangrendszer, $x=$ Vass Imre-barlang, * = ÁCS \& KONTSCHÁN (2014) alapján).

Table 1. The found mesostigmatans in present study, in the Domica Cave (KovÁč et al. 2005) and in the monograph of Baradla (DuDICH 1932) (+ = Baradla-Domica Cave System, $x=$ Vass Imre Cave, * $=$ after Ács \& KONTSCHÁN (2014)),

\begin{tabular}{|c|c|c|c|}
\hline faj/élöhely & 2013-2014-es vizsgálat & Domica-barlang & DUDICH (1932) \\
\hline Gamasina & (15 faj) & (21 faj) & (15 faj) \\
\hline Arctoseius semiscissus & $\times$ & + & \\
\hline Cyrtolaelaps chiropterae & $\times$ & + & \\
\hline Cyrtolaelaps mисronatus & $\times$ & + & + \\
\hline Gamasellodes bicolor & + & & \\
\hline Geholaspis longispinosus* & + & + & + \\
\hline Geholaspis longulus* & + & + & \\
\hline Macrocheles montanus* & + & & \\
\hline Macrocheles punctatisimilis* & + & & \\
\hline Macrocheles similiopacus* & + & & \\
\hline Hypoaspis aculeifer & + & + & \\
\hline Pergamasus crassipes & + & + & + \\
\hline Prozercon tragardhi & $+\times$ & + & \\
\hline Veigaia nemorensis & $+\times$ & + & \\
\hline Vulgarogamasus oudemansi & $+\times$ & & \\
\hline Zerconopsis remiger & + & & \\
\hline Uropodina & (4 faj) & (5 faj) & (0 faj) \\
\hline Nenteria dobrogensis & + & + & \\
\hline Uroobovella advena & + & + & \\
\hline Uropoda kargi & + & & \\
\hline Uroseius infirmus & + & & \\
\hline
\end{tabular}

\section{A barlangban megtalált fajok listája}

\section{Mesostigmata rend}

\section{Gamasina alrend}

Hypoaspididae család

\section{Hypoaspis aculeifer (CANESTRINI, 1883)}

Rövid jellemzés: A test ovális alakú. A ivari lemez olyan keskeny, mint az anális lemez (1. ábra). A 2., a 3. és a 4. lábon a tü alakú szőrök mellett erös tüske alakú szőrök vannak. Ismert hazai előfordulás: Bakony, Vértes (KONTSCHÁN \& UJVÁRI 2012).

Barlangi adata: Aggtelek, Baradla-barlang, Színház-terem, 2014.03.06. 
Ascidae család

Arctoseius semiscissus (BERLESE, 1892)

Rövid jellemzés: A dorzális lemez egységes, csak egy kicsi kétoldali behasadás figyelhető meg a közepén. Az összes dorzális szőr sima, hosszú tű alakú (2. ábra). Az anális lemez kör alakú.

Ismert hazai előfordulás: Hortobágyi Nemzeti Park (KANDIL 1983).

Barlangi adata: Jósvafö, Vass Imre-barlang, Omladék-terem, 2014.03.07.

Zerconopsis remiger (KRAMER, 1876)

Rövid jellemzés: Az összes dorzális szőr sima tü-alakú, kivéve az s5, Z3 és Z5 szöröket, amelyek spatula alakúak. A dorzális lemez a szegélyeinél alveoláris mintázatot visel (3. ábra).

Ismert hazai előfordulás: Hortobágyi Nemzeti Park, Budai-hegység (KANDIL 1983, KONTSCHÁN \& UJVÁRI 2012).

Barlangi adata: Aggtelek, Baradla-barlang, Dancza-nyelő, vékony gombával borított gerendáról, 2013.03.22-04.09.

\section{Gamasellodes bicolor (BERLESE, 1918)}

Rövid jellemzés: A dorzális lemez kettéosztott. Az összes dorzális szőr sima, rövid és tű alakú, kivéve a Z5, ami négyszer, és az S5, ami kétszer olyan hosszú, mint a J4. Ovális mintázat figyelhetö meg a kutikula kaudális részén (4. ábra).

Ismert hazai előfordulás: Vértes, Balaton-felvidék, Bátaapáti (SALMANE \& KONTSCHÁN 2006, KONTSCHÁN \& UJVÁRI 2012).

Barlangi adata: Aggtelek, Baradla-barlang, Denevér-ág, humusz kövek alól, 2013.03.22-04.09.; Aggtelek, Baradla-barlang, Színház-terem, 2014.03.06.

Zerconidae család

\section{Prozercon tragardhi (HALBERT, 1923)}

Rövid jellemzés: A j5 és az $R$ sor kivételével az összes dorzális szőr pillás. Az opisthonotális J, Z, S szörök mindegyike közepesen hosszú, erősen pillázott, vagy ecsetszerü. A J sor minden tagja eléri a következő eredését. Z1 és S1 közel azonos méretü és Z1 kissé előrébb helyezkedik el (5. ábra).

Ismert hazai előfordulás: Budai-hegység, Velencei-hegység, Bakony, Vértes, Mecsek, Aggteleki-karszt, Bükk, Cserhát, Börzsöny (SALMANE \& KONTSCHÁN 2006, UJvÁRI \& KONTSCHÁN 2007, KONTSCHÁN \& UJVÁRI 2012).

Barlangi adata: Aggtelek, Baradla-barlang, Dancza-nyelö, vékony gombával borított gerendáról, 2013.03.22-04.09.; Jósvafö, Baradla-barlang, közel a 42+ mérési ponthoz (a Pindusnál), 2013.03.22-04.09.; Jósvafö, Vass Imre-barlang, Omladék-terem, 2014.03.07. 

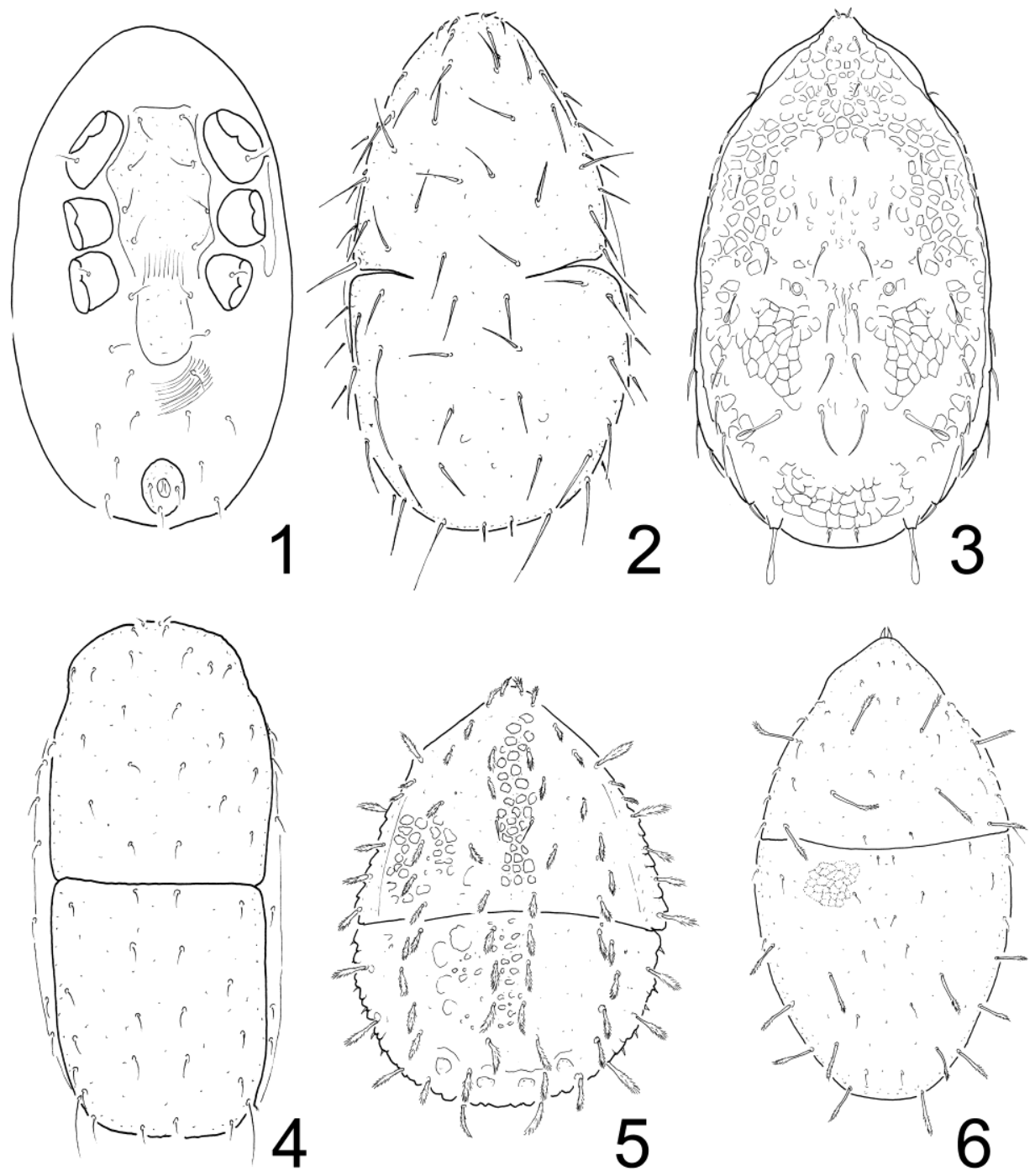

1-6. ábrák. A megtalált Mesostigmata atkák. 1: Hypoaspis aculeifer (CANESTRINI, 1883); 2: Arctoseius semiscissus (BERLESE, 1892); 3: Zerconopsis remiger (KRAMER, 1876);

4:, Gamasellodes bicolor (BERLESE, 1918); 5: Prozercon tragardhi (HALBERT, 1923); 6: Cyrtolaelaps chiropterae KARG, 1971.

Figures 1-6. The found mesostigmatans. 1: Hypoaspis aculeifer (CANESTRINI, 1883);

2: Arctoseius semiscissus (BERLESE, 1892); 3: Zerconopsis remiger (KRAMER, 1876);

4: Gamasellodes bicolor (BERLESE, 1918); 5: Prozercon tragardhi (HALBERT, 1923); 6: Cyrtolaelaps chiropterae KARG, 1971 
Rhodacaridae család

\section{Cyrtolaelaps chiropterae KARG, 1971}

Rövid jellemzés: Az elülső dorzális lemezen négy pár hosszabb, erősen pillás szőr van, míg a hátulsó dorzális lemezen hat pár helyezkedik el (6. ábra). A ventroanális lemezen hat pár szőr található.

Barlangi adata: Jósvafö, Vass Imre-barlang, Omladék-terem, 2014.03.07.

Megjegyzés: Magyarország faunájára új faj. Barlanglakó, denevérürülékben élő atkafaj, amely egész Európában előfordul, de sehol sem gyakori (KARG 1993).

\section{Cyrtolaelaps mucronatus (G. \& R. CANESTRINI, 1881)}

Rövid jellemzés: Az elülső dorzális lemezen két pár hosszabb, erősen pillás szőr van, míg a hátulsó dorzális lemezen egy pár helyezkedik el a megtalált nimfa stádiumú egyedeken, ezen a pajzson számos extra szőrt lehet találni (7. ábra).

Barlangi adata: Jósvafö, Vass Imre-barlang, Omladék-terem, 2014.03.07.

Megjegyzés: Magyarország faunájára új faj. Egész Európában elterjedt faj, amely szántóföldeken, erőkben, kisemlősök fészkeiben és barlangokban is előfordul (KARG 1993).

Parasitidae család

Pergamasus crassipes (LinNAEUS, 1758)

Rövid jellemzés: Szternális és genitális szőrök simák, tü alakúak. Az endogínium két kör alakú képletből (vaginális mirigyek) és a közöttük levő középnyúlványból áll. A középnyúlvány vége igen változatos lehet.

Ismert hazai előfordulás: Zemplén, Tihany, Oroszlány, Paks, Bakony, Balaton-felvidék, Vértes, Bátaapáti (SALMANE \& KONTSCHÁN 2006, KONTSCHÁN \& UJVÁRI 2012).

Barlangi adata: Jósvafö, Baradla-barlang, közel a 42+ mérési ponthoz (a Pindusnál), 2013.03.22-04.09.

Vulgarogamasus oudemansi (BERLESE, 1903)

Rövid jellemzés: Az episztoma 3 csúcsú, az első szternális szőr a mell-lemezen van. A mell-lemez ráncolt mintázatú, a preszternális lemezek kicsik, háromszögletesek. A középső genitális lemez hegyes végcsúccsal és két kis oldalsó csúccsal rendelkezik.

Ismert hazai előfordulás: Hortobágyi Nemzeti Park (KANDIL 1983).

Barlangi adata: Jósvafö, Vass Imre-barlang, talajcsapda, a bejárattól nem messze, 2013.03.22-04.09.; Jósvafö, Vass Imre-barlang, a Dzsungel kezdeténél, 2014.03.26-04.23. 
Veigaiidae család

Veigaia nemorensis (C. L. KoCH, 1839)

Rövid jellemzés: A dorzális lemez két részre osztott (8. ábra). Az episztomának két erösen fogazott oldalsó nyúlványa van, középső része Y-alakú, rajta apró tüskékkel. Az episztoma alapi részén két apró háromszög alakú tüske van (9. ábra).

Ismert hazai előfordulás: Hortobágyi Nemzeti Park, Bátaapáti, Bakony, Dunántúliközéphegység (KANDIL 1983, SALMANE \& KONTSCHÁN 2006, KONTSCHÁN \& UJVÁRI 2012),

Barlangi adata: Aggtelek, Baradla-barlang, Dancza-nyelő, vékony gombával borított gerendáról, 2013.03.22-04.09.; Aggtelek, Baradla-barlang, Denevér-ág, bejárat közelében, avarból, 2013.03.22-04.09.; Jósvafö, Vass Imre-barlang, a Dzsungel kezdeténél, 2014.03.26-04.23.

\section{Uropodina alrend}

Nenteriidae család

Nenteria dobrogensis FEIDER \& HUȚU, 1971

Rövid leírás: A genitális lemez nagy, nyelv alakú. A teljes test kör alakú bemélyedésekkel díszített. A genitális lemez elülső szegélye a második láb csípőjének a hátulsó szegélyéig ér. A ventroanális szőrök a végükön pillásak (10. ábra).

Barlangi adata: Jósvafö, Baradla-barlang, közel a 42+ mérési ponthoz (a Pindusnál), 2013.03.22-04.09.

Megjegyzés: Magyarország faunájára új faj. Koprofil faj, elsődlegesen denevérguanóban fordul elö. Eddig csupán Szlovákiából (MAŠÁN 2001), Lengyelországból és Romániából ismertük (WIŚNIEWSKI \& HIRSCHMANN 1993).

Urodinychidae család

Uroobovella advena (TRÄGÅRDH, 1912)

Rövid jellemzés: A test ovális alakú, dorzo-ventrálisan lapított. A dorzális és a ventrális pajzs apró, kör alakú díszítéssel borított. A posztdorzális pajzs háromszög alakú, rajta egy pár bunkós szőrrel (11. ábra). A ventrális és a dorzális lemez szőrei a kaudális részeken bunkósak, míg a többi sima, tü alakú. Az ivari lemez pajzs alakú, vége hegyes. A peritrema S-alakú.

Ismert elöfordulás: Bükki Nemzeti Park, Bakony (Wiśniewski 1996, KONTSCHÁN \& UJVÁRI 2012).

Barlangi adata: Aggtelek, Baradla-barlang, Dancza-nyelö, vékony gombával borított gerendáról, 2013.03.22-04.09.; Aggtelek, Baradla-barlang, Denevér-ág, humusz kövek alól, 2013.03.22-04.09.; Jósvafö, Baradla-barlang, közel a 42+ mérési ponthoz (a Pindusnál), 2013.03.22-04.09. 

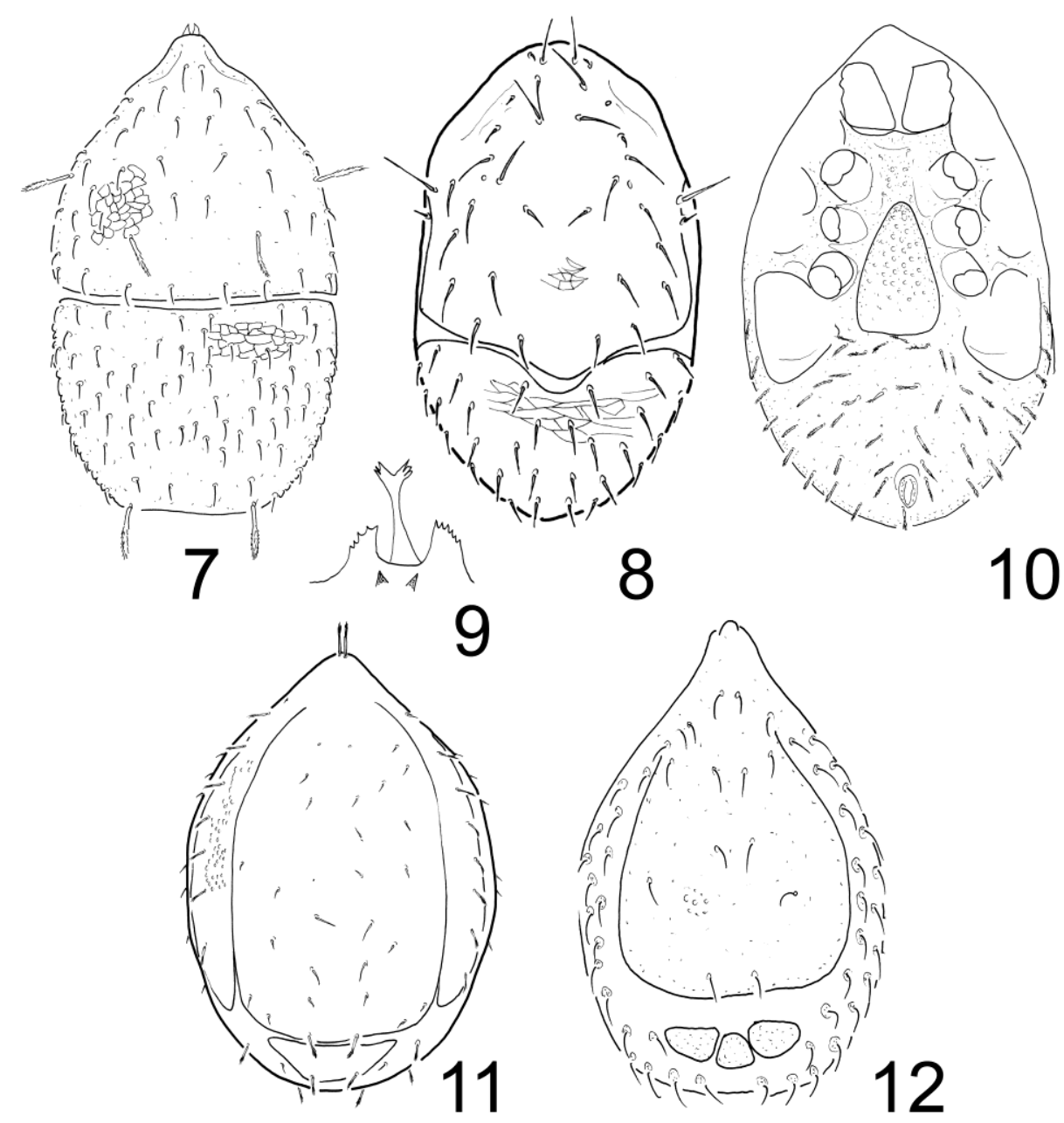

7-12. ábrák. A megtalált Mesostigmata atkák (folytatás). 7: Cyrtolaelaps mucronatus (G. \& R. CANESTRINI, 1881); 8: Veigaia nemorensis (C. L. KoCH, 1839); 9: V. nemorensis episztomája; 10: Nenteria dobrogensis FEIDER \& HUȚU, 1971 11: Uroobovella advena (TRÄGÅRDH, 1912); 12: Uroseius infirmus (BERLESE, 1887).

Figures 7-12. The found mesostigmatans (continued). 7: Cyrtolaelaps mucronatus (G. \& R. CANESTRINI, 1881); 8: Veigaia nemorensis (C. L. KOCH, 1839); 9: epistome of V. nemorensis; 10: Nenteria dobrogensis FEIDER \& HUȚU, 1971; 11: Uroobovella advena (TRÄGÅRDH, 1912); 12: Uroseius infirmus (BERLESE, 1887). 
Uropodidae család

Uropoda kargi HIRSCHMANN \& ZIRNGIEBL-NICOL, 1969

Rövid jellemzés: A test ovális alakú. A ventrális oldal kaudális részén bőrszerủ, míg az ivarlemez alapi részénél, az ivarlemezen és a dorzális oldalon ovális díszítés van. A marginális pajzs körbe ér, rajta apró, tű alakú szörök vannak.

Ismert hazai előfordulás: Vértes, Bakony (KONTSCHÁN \& UJVÁRI 2012).

Barlangi adata: Jósvafö, Baradla-barlang, közel a 42+ mérési ponthoz (a Pindusnál), 2013.03.22-04.09.

Trachytidae család

Uroseius infirmus (BERLESE, 1887)

Rövid jellemzés: A test körte alakú, a háti részen egy három részből álló posztdorzális lemez figyelhető meg (12. ábra). A ventrális szörök hosszúak, tủ alakúak. A metapodális lemez nagy és kör alakú. A mell-lemez elején egy három félkörös megvastagodott kutikula rész látható.

Ismert hazai előfordulás: Túrkeve, Hortobágyi Nemzeti Park (HIRSCHMANN 1981).

Barlangi adata: Aggtelek, Baradla-barlang, Dancza-nyelő, vékony gombával borított gerendáról, 2013.03.22-04.09.; Jósvafö, Baradla-barlang, közel a 42+ mérési ponthoz (a Pindusnál), 2013.03.22-04.09.

\section{Felszíni minták}

A barlangok közelében, a felszínen talált fajok listáját a 2. Táblázatban adom meg.

\section{Értékelés}

Ha eredményeimet összehasonlítjuk DuDICH (1932) korábbi munkájával, azt tapasztaljuk, hogy a Baradla monográfiában szerepelö egy Mesostigmata fajjal szemben, most 19 faj került elő. Mindezek mellett, DUDICH professzor nem említ korongatkákat a barlangból, és az általam kimutatott fajok java része most elöször került elö onnan. Több olyan faj viszont, amelyet korábban a Baradla-barlangból már ismertek, most nem került elő a vizsgálatok során. Összevetve a megtalált fajok listáját KovÁČ et al. (2005), a Domica-barlangban végzett feltárásaival, elmondható, hogy ott tíz fajjal többet találtak, viszont számos olyan faj került elő jelen vizsgálat során, amely a barlangrendszer szlovákiai részéből még nem ismert (1. táblázat). 
2. táblázat. A barlangokban és a felszínen talált fajok listája (* = ÁCS \& KONTSCHÁN (2014) alapján). Table 2. Mesostigmata species collected in the caves and in the surface (* $=$ after ÁCS \& KONTSCHÁN (2014)).

\begin{tabular}{|c|c|c|}
\hline faj/élőhely & barlangban & barlangon kívül \\
\hline \multicolumn{3}{|l|}{ Gamasina } \\
\hline Arctoseius semiscissus & + & \\
\hline Asca aphidioides & & + \\
\hline Cyrtolaelaps chiropterae & + & \\
\hline Cyrtolaelaps mucronatus & + & \\
\hline Gamasellodes bicolor & + & \\
\hline Geholaspis longispinosus* & + & + \\
\hline Geholaspis longulus* & + & \\
\hline Holoparasitus calcaratus & & + \\
\hline Hypoaspis aculeifer & + & \\
\hline Macrocheles montanus* & + & \\
\hline Macrocheles punctatisimilis* & + & \\
\hline Macrocheles similiopacus* & + & \\
\hline Pergamasus crassipes & + & \\
\hline Prozercon tragardhi & + & \\
\hline Veigaia nemorensis & + & + \\
\hline Vulgarogamasus oudemansi & + & \\
\hline Zercon baloghi & & + \\
\hline Zerconopsis remiger & + & \\
\hline \multicolumn{3}{|l|}{ Uropodina } \\
\hline Cilliba selnicki & & + \\
\hline Discourella modesta & & + \\
\hline Nenteria dobrogensis & + & \\
\hline Oodinychus karawaiewi & & + \\
\hline Trachytes aegrota & & + \\
\hline Trachytes baloghi & & + \\
\hline Uroobovella advena & + & \\
\hline Uropoda kargi & + & \\
\hline Uroseius infirmus & + & \\
\hline
\end{tabular}

A megtalált fajok között a barlangi életmódhoz adaptálódott, troglobiont faj eddig nem került még elő. A barlangi életmódhoz még leginkább kötődő fajok az eutroglofil csoportba sorolhatóak, ezek elsődlegesen a barlangban kialakult speciális biotópokat kedvelik. Elsődlegesen a denevérek ürülékein alakulnak ki ilyen jellegü atkaközösségek, amelyek jól jellemezhetőek a Nenteria dobrogensis és Uroobovella advena korongatka fajokkal és a Cyrtolaelaps chiropterae Gamasida atka fajjal. Az utóbbi csak denevérguanóban található, míg a másik két faj más barlangi élőhelyeket is benépesíthet (MAŠÁN 2001). Az Uroobovella advena faj jól ismert barlanglakó korongatka, amely Románia, Szlovákia és Magyarország barlangjaiból ismert, ahol a denevérguanó a legfontosabb élőhelye (MAŠÁN 2001). A Nenteria dobrogensis hazánkból eddig nem ismert korongatka faj, amelyet viszont több romániai és szlovákiai barlangból is jeleztek korábban (MAŠÁN 2001, KovÁČ et al. 2005). A Cyrtolaelaps chiropterae és Cyrtolaelaps mucronatus fajokat korábban szintén nem ismertük hazánkból, szlovákiai és alpesi barlangokból többfelé kimutatták. Több kutató szintén eutroglofil fajnak tartja a Prozercon tragardhi és Veigaia nemorensis fajokat is 
(KovÁČ et al. 2005), melyek hazánkból több helyröl is ismertek, és nem csak barlangokban, hanem talajban, avarban és kisemlősök fészkeiben is elöfordulnak (KARG 1993).

A többi megtalált Gamasida atka barlangi vendégnek tekinthetö, és mivel ezek kivétel nélkül ragadozó életmódúak, feltételezhetjük, hogy a barlangi egyéb gerinctelenek, mint potenciális zsákmányállatok miatt húzódnak be a barlangba. Kivételt képez az Uroseius infirmus faj, amely nem ragadozó életmódú. Ezt a fajt feltételezhetően a különbözö élőhelyek szerves anyagain megjelenő gombák vonzhatják a barlangokba.

A 2. táblázatból jól látható, hogy a barlangi fauna jelentősen különbözik a felszíni faunától, a közös fajok száma nagyon alacsony. Csupán két faj, a korábban közölt Geholaspis longispinosus (ÁCS \& KONTSCHÁN 2014) és a most bemutatott Veigaia nemorensis fordult elő a barlangban és a barlangon kívüli részeken is.

Köszönetnyilvánítás. Köszönöm a gyüjtésben résztvevő kollégának, hogy az általuk gyűjtött atkákat a rendelkezésemre bocsájtották.

\section{Irodalomjegyzék}

Ács, A. \& Kontschán, J. (2014): Contribution to the Macrochelidae Vitzthum, 1930 fauna of the Carpathian Basin and the Balkan Peninsula (Acari: Mesostigmata). Opuscula Zoologica Budapest 45(2): 109-118.

Dudich, E. (1932): Biologie der Aggteleker Tropfsteinhöhle „Baradla” in Ungarn. Speläologische Monographien XIII, Verlag Speläologisches Institut, Wien, 246 pp.

HiRSCHMANN, W. (1981): The Uropodina fauna of the Hortobágy National Park (Acari). In: Mahunka, S. (ed.): The fauna of the Hortobágy National Park I. Akadémiai Kiadó, Budapest, pp. $341-342$.

KARG, W. (1993): Acari (Acarina), Milben Parasitiformes (Anactinochaeta) Cohors Gamasina Leach. Raubmilben. Gustav Fischer Verlag, Jena, Stuttgart, New York, 523 pp.

KandiL, M. M. (1983): The Mesostigmata fauna of the Hortobágy National Park (Acari). In: MAHUNKA, S. (ed.): The fauna of the Hortobágy National Park II. Akadémiai Kiadó, Budapest, pp. 365-373.

KONTSCHÁN, J. \& UJVÁRI, Zs. (2012): A Dunántúli-középhegység szabadon élő korongatkái és nyügatkái (Acari: Mesostigmata: Uropodina, Gamasina, Sejina és Antennophorina). A Bakony természettudományi kutatásának eredményei XXXII. Magyar Természettudományi Múzeum, Zirc, 118 pp.

Kováč, L., Mock, A., LuptáčıK, P., KoŠel, V., FenĎA, P., Svatoñ, J. \& MašÁn, P. (2005): Terrestrial arthropods of the Domica Cave system and the Ardovská Cave (Slovak Karst) principal microhabitats and diversity. In: TAJOvSKÝ, K., SCHLAGHAMERSKÝ, J. \& PižL, V. (eds): Contributions to Soil Zoology in Central Europe I. ISB AS CR, České Budějovice, pp. 61-70.

MAŠÁN, P. (2001): Roztoče kohorty Uropodina (Acarina, Mesostigmata) Slovenska [Mites of the cohort Uropodina in Slovakia]. Annotationes Zoologicae et Botanicae 223: 1-319.

PETÉNYI S. J. (1854): Bihar vármegyének Sebes és Fekete Kőrös közti hegyláncolatain tett természettudományi utazása. Új Magyar Múzeum 4(2): 427-425. 
SAlmane, I. \& Kontschán, J. (2006): Soil Mesostigmata mites (Acari, Parasitiformes) from Hungary II. Latvijas Entomologs 43: 14-17.

SZALAY, L. (1931): Adatok az Aggteleki barlang Arachnoidea-faunájának ismeretéhez. Állattani Közlemények 29: 15-32.

UJVÁRI, Zs. \& KONTSCHÁN, J. (2007): New occurrences of the Zerconid mites from Hungary (Acari: Mesostigmata). Folia historico-naturalia Musei Matraensis 31: 107-114.

WIŚNIEWSKI, J. (1996): The Uropodina fauna (Acari) from the Bükk National Park (N. Hungary). In: MahunkA, S. (ed.): The fauna of the Bükk National Park II. Hungarian Natural History Museum, Budapest, pp. 485-486.

WiŚNIEWSKI, J. \& HiRSCHMANN, W. (1993): Gangsystematik der Parasitiformes. Teil 548. Katalog der Ganggattungen, Untergattungen, Gruppen und Arten der Uropodiden der Erde. Acarologie. Schriftenreihe für vergleichende Milbenkunde 40: 1-220. 


\title{
Data to the mesostigmatans of the caves of Aggtelek Karst (Acari)
}

\section{JENŐ KONTSCHÁN}

Plant Protection Institute, Centre for Agricultural Research, Hungarian Academy of Sciences, P.O. Box 102, H-1525 Budapest, Hungary

E-mail: kontschan.jeno@agrar.mta.hu

\begin{abstract}
ÁLLATTANI KÖZLEMÉNYEK (2018) 103(1-2): 33-45.
Abstract. During the study of the mesotigmatans of two caves in the Aggtelek Karst (Baradla and Vass Imre Caves, NE Hungary) 14 species are reported. Three of them (Cyrtolaelaps chiropterae KARG, 1971; Cyrtolaelaps mucronatus (G. \& R. CANESTRINI, 1881); Nenteria dobrogensis FEIDER \& HuțU, 1971) are new to the fauna of Hungary. 13 species were collected from the Baradla Cave and six from the Vass Imre Cave, three species were found in both caves. No troglobiont Mesostigmata have been found in these caves, but seven of the species might be considered as eutroglophil. Parallel sampling from a surface habitat at the entrance of the Baradla Cave resulted ten species, from which only two have also been found in the caves.
\end{abstract}

Key words: Mesostigmata, caves, Aggtelek Karst, Hungary. 